(C) Voronkova H.V., Smagliuk L.V., Karasiunok A.Y.

UDC 616.314:611.716.4-007.12:[616-02+616-07]

DOI https://doi.org/10.31718/mep.2019.23.3-4.10

\title{
ETIOPATHOGENESIS AND DIAGNOSTICS OF THE MANDIBULAR PERMANENT FIRST MOLARS RETENTION
}

\author{
Voronkova H.V., Smagliuk L.V., Karasiunok A.Y.
}

Ukrainian Medical Stomatological Academy, Poltava

Прорізування першого постійного моляра дуже важливе, оскільки воно забезпечує гармонію росту обличчя і достатню оклюзійну підтримку. Затримка прорізування цього зуба може викликати морфологічні, функціональні та естетичні порушення. До них відносяться зменшення вертикальних розмірів нижньої частини обличчя, екструзію зубів антагоністів, порушення прикусу, формування фолікулярної кісти, перикоронального запалення, і резорбцію коренів сусідніх зубів, так і функціональні проблеми з боку зубо-щелепної ділянки та ін. У зв'язку з цим, питання етіології, патогенезу, ранньої діагностики та подальшої тактики лікування ретенції нижніх перших постійних молярів $\epsilon$ дуже актуальним для сучасного ортодонта. Матеріали і методи дослідження. У статті проведений огляд та аналіз літератури щодо етіології, патогенезу, ранньої діагностики ретенції нижніх перших постійних молярів. Результати. Аналіз літератури вказав на незначну кількості досліджень щодо порушення прорізування перших молярів нижньої щелепи. В більшості випадків вони представлені клінічними випадками. За даними світової літератури поширеність затримки прорізування першого моляра нижньої щелепи становила від 0,01\% до 0,04\%. Дані літератури вказують на те, що ретенція нижнього першого моляру - це поліфакторне захворювання. До етіологічних чинників автори відносять загальні та місцеві фактори. Місцеві фактори, що викликають затримку прорізування зубів, включають порушення шляху прорізування зубів, аномалію форми зуба, гіперплазію, зміщення зачатку через кісту і пухлину, втрату простору для прорізування, фіброз ясен, ідіопатичні умови. Системні фактори включають ендокринні розлади, такі як гіпотиреоз, гіпертиреоз, гіпопаратиреоз, рахіт, краніофаціальну гіпертрофію. В літературному огляді представлені морфологічні та рентгенологічні діагностичні критерії порушення прорізування перших постійних нижніх молярів. Так, корейські вчені запропонували визначати глибину ретенції, кут нахилу та простір для їх прорізування на панорамних рентгенограмах. В огляді представлена класифікація типів ретенції перших постійних молярів нижньої щелепи.

Ключові слова: ретенція зубів, порушення прорізування нижнього першого моляра, затримка прорізування зубів, діагностика порушень прорізування перших постійних нижніх молярів.

The eruption of the first permanent molars is very important as it provides the harmony of the growth of the face and sufficient occlusion support. A delay in the eruption of this tooth can cause morphological, functional and aesthetic disturbances. These include reduced vertical size of the lower face, extruding the antagonist teeth, malloclusion formation, follicular cyst formation, pericoronal inflammation, and roots resorbtion of the adjacent teeth, as well as functional problems of dentoalveolar area, etc. In this regard, the issue of etiology, pathogenesis, early diagnostics and further treatment of lower first permanent molars retention is very relevant for modern orthodontics. In the literary review, morphological and radiological diagnostic criteria of eruption of first permanent lower molars have been presented. Materials and methods of the research. The article reviews and analyzes literature on the etiology, pathogenesis, early diagnostics of retention of the lower first permanent molars. Results The analysis of the literature pointed to a small number of studies regarding the disrupted eruption of first lower permanent molars. In most cases, they are presented as clinical cases. According to the world literature, the prevalence of delayed eruption of the first molar of the mandible was $0.01 \%$ to $0.04 \%$. Data from the world literature indicate that the retention of the lower first molar is a polyfactoral disease. According to the etiological factors authors distinguish general and local. Local factors causing delay in teeth eruption include impaired pathway for teeth eruption, abnormality of the tooth form, hyperplasia, displacement of the rudiment because of the cyst and the tumour, loss of space for eruption, gingival fibrosis, idiopathic conditions. Systemic factors include endocrine disorders such as hypothyroidism, hyperthyroidism, hypoparathyroidism, rickets, craniofacial hypertrophy. In the literary review morphological and radiological diagnostic criteria of eruption disturbance of the first permanent lower molars are presented. Thus, the Korean scientists proposed to determine the depth of the retention, the angle of inclination and the space for their eruption on panoramic radiographs. The review presents the classification of retention types for the first permanent molars of the mandible.

Key words: dental retention, disturbances in the eruption of the lower first molars, delayed teeth eruption, diagnostics of first permanent lower molars eruption violations.

\section{Introduction}

According to the data of modern literature, in many countries of the world there is an increase in the frequency of dentofacial anomalies, including dental retention $[1,2,3]$. According to studies of various scientists, the delay in the eruption ranges from $0.8 \%$ to $17.4 \%$ of cases $[1,4]$.

Both temporary and permanent teeth may remain impacted. Among the permanent teeth, retention of the maxillary canines and mandibular premolars is more often observed; then retention of third molars on the lower

To cite this english version: H.V. Voronkova, L.V. Smagliuk, A.Y. Karasiunok Etiopathogenesis and diagnostics of the mandibular permanent first molars retention. a literature review. . // The Medical and ecological problems. - 2019. - Vol 23, № 3-4. - P. 41-45. 
jaw follows; and, more rarely, the retention of the central and lateral incisors $[5,6,7]$ is observed. Delayed eruption of the first mandibular molar is rare. Hence, P.S. Grover, L. Lorton [4] determined that its prevalence was less than $0.01 \%$, and R.M. Kramer, A.C. Williams [8] reported that the prevalence of this pathology was $0.04 \%$. At the same time, eruption of the first permanent molar is very important as it provides the harmony of the growth of the face and sufficient occlusion support. Disturbance in the eruption of this tooth can cause many problems, such as reduced vertical size of the lower face, extrusion of antagonist teeth, malocclusion, follicular cyst formation, pericoronal inflammation, and resorption of the roots of adjacent teeth [9-11]. In this regard, issues of etiology, pathogenesis, early diagnosis and further treatment of retention of the lower first permanent molars are very relevant for a modern orthodontist. Therefore, a review of modern world literature, which would reveal these issues, became the aim of our research.

\section{Materials and methods}

A literary study was conducted using the Medline database and Google Scholar database. Keywords used in the search were "dental retention", "disturbances in the eruption of the lower first molar", "delayed teeth eruption", "diagnostics of first lower molars eruption violations".

\section{Results}

Teeth eruption is a physiological process that greatly affects the normal development of the craniofacial complex $[12,13]$.

In the special literature, retention is considered as a disturbance in the process of teeth eruption [14, 15]. Some authors consider impacted tooth as the one which has not erupted after end of the period of its physiological eruption, with the completed formation of the root, and with periodontal ligament located in the bone. Other specialists relate impacted teeth to those ones which have not erupted within two years after the period of their physiological eruption [16].

For diagnostic purposes, impacted teeth are classified according to three states: impaction, primary and secondary retention [17].

1. Impaction is the termination of tooth eruption caused by a clinically or radiologically identified barrier on the way of the eruption pathway or due to the incorrect position of the tooth.

2. Primary retention is defined as the termination of the eruption of a normally positioned and normally developed tooth before eruption through the gum without a physical barrier on the way of the eruption, and when the tooth eruption is delayed for more than two years.

3. Secondary retention is the termination of tooth eruption after appearance in the oral cavity without a physical barrier or ectopia of the tooth.

Most experts associate teeth eruption with the degree of their roots formation. According to Anastasia KelekisCholakis, William Wiltchire (2006), the eruption of permanent teeth usually begins after the formation of one-fourth of their roots [18].

In another study, Haavikko [19] and Gron [20] reported that teeth erupted during the formation stage of approximately two-thirds of the root. According to other experts [21], teeth eruption can also occur with halfly formed root of the tooth.

However, Marks and Schroeder (1996) [22] observed teeth eruption without roots, which means, in their opin- ion, that the formation of the root itself is not a direct condition for teeth eruption, but it can speed up this process. The formed root apex of the impacted tooth, according to G.S. Gordon-Jury et al. [23], indicates a complete loss of potency to self-eruption.

Previous publications on the retention of the first permanent molars constitute mainly reviews of clinical cases with a small number of patients (Glass, 1951; Jerrold, 1966; Robinson, 1974; Watkins and Tucker, 1977; Mellor, 1981; Lapeer, 1988; Raghoebar et al. , 1990; Groper, 1992; Hedge and Munshi, 2001), and obviously there is a lack of knowledge on the etiology and the possibility of restoring the process of their eruption (Kaban et al., 1976; Duncan and Ashrafi, 1981; Oliver and Hunter, 1986; Spieker, 2001) [24].

According to Kwon et al. [25], among 2.219 children examined at a primary school in Korea, the following average term for the eruption of the first mandibular molars was determined: for boys -6.22 years, for girls -6.12 years. According to the studies by Helm and Seidler [26], the term for eruption of the first mandibular molar in Danish children was 6.21 years for boys, 6.02 years for girls, and according to Ekstrand et al. [27]: 6.3 years for boys and 6.1 years for girls.

The authors did not substantiate the difference between the frequency of delayed eruption of the first mandibular molar by gender, but the total number of boys with this pathology was by 1.5 times higher than that of girls, and the difference in the prevalence of the left and right side was not significant.

Disturbance in the eruption of permanent teeth may be caused by systemic factors associated with endocrine abnormalities and syndromes or local factors [28]. Local factors causing delay in teeth eruption include impaired pathway for teeth eruption, abnormality of the tooth form, hyperplasia, displacement of the rudiment because of the cyst and the tumour, loss of space for eruption, gingival fibrosis, idiopathic conditions. Systemic factors include endocrine disorders such as hypothyroidism, hyperthyroidism, hypoparathyroidism, rickets, craniofacial hypertrophy.

Several authors (Reid, 1954; Brady, 1990; Ireland, 1991; DiBiase and Leggat, 2000), given the large number of hereditary cases, suggest that disturbance in the eruption may have a genetic component. There is evidence that the retention of molars is also under genetic control (Baccetti, 2000). Scientists point out that eruption disturbances are associated with the Mendelian inheritance scheme (Shokeir, 1974), and teeth eruption may be affected by a number of syndromes (cleidocranial dysostosis, osteopetrosis, etc.) [29].

As for the etiology of retention in the very first lower molars, this question has not been studied in detail in the literature. In particular, Marsuzaki et al. [30] investigated the reasons for the eruption delay of the very first lower molar. A total of eleven patients (4 boys and 7 girls with an average age of 9.5 years) were examined with the primary delay in teeth eruption. An estimation of clinical, radiological and histopathologic researches was conducted in order to identify the factors that prevent spontaneous eruption of the examined teeth, the choice of further surgical intervention and the course of the postoperative period. Histopathological diagnoses of patients included 3 odontogenic tumours, 2 odontogenic cysts and 6 hyperplasias of dental follicles.

In addition, Philipsen et al. [31, 32] also conducted histological studies of the mucous membrane, which 
covers the impacted teeth (opercules). The material of 74 impacted teeth (first and second molars) was examined. In $24.3 \%$ of cases, the "classic" odontogenic tumours were diagnosed: ameloblastic fibroma (7), ameloblastic fibrodentinoma (6), ameloblastic fibroodontoma (4), and complex odontoma (1). $29.7 \%$ of the sample showed unidentified odontogenic lesion of hamartomatous nature, which was called giant-cell odontogenic fibromatosis. Thus, odontogenic tumours were diagnosed in $54.1 \%$ of the samples. Histomorphological changes were not detected in other 34 samples $(45.9 \%)$. Odontogenic tumours were significantly more often associated with first molars than with other molars (8:1 ratio). Giant-cell odontogenic fibromatosis had a close connection with impacted mandibular molars. In addition, odontogenic lesions of the mucous membrane over the first molars of the mandible were more common.

C. Bereket, N. Cakir-Ozkan, I. Sener et al. (2011) [33] believe that one of the main etiological factors is the medial inclination of the eruption of the first mandibular molar for an unknown reason.

A study of 24.000 Danish children showed that there was a significant correlation between the period of teeth eruption within one field of innervation (Parner et al., 2002). Thus, the period of eruption of the first permanent molar in the mandible is closely related to other molars of the mandible. At the same time, there is no close connection between the first molars, incisors or premolars. Considering that mandibular molars have a separate innervation (Chavéz-Lomeli et al., 1996; Kjær, 1998) in relation to incisors and premolars, the authors suggest that innervation could have an effect on the eruption process. Recently, the association between innervation and eruption has been proven experimentally (Fujiyama et al. (2004) [34].

A number of scientists point out that local disorders of innervation caused by viral damage to the nerve pathways (Herpes zoster, epidemic mumps) can lead to delayed teeth eruption (Bang et al., 1995; Becktor et al., 2002). Short roots, osteonecrosis, periodontitis, retention, odontalgia, scars, dental agenesis, calcined and devitalized pulp, internal resorption of the roots are clinical manifestations that are described in combination with infectious lesion of the trigeminal nerve branches caused by herpes zoster (Cooper, 1977; Schwartz and Kvorning, 1982; Wright et al., 1983; Smith et al., 1984; Garty et al., 1985; Solomon et al., 1986; Goon and Jacobsen, 1988) [35]. One of the ways in which a viral attack can affect the development and teeth eruption is the spread of the virus through the peripheral nerve pathways to the teeth. This can cause temporary demyelination of nerve fibers, which can lead to decreased activity of nerve endings. It has been proven that demyelinated nerve endings are in close proximity to the tooth (Lambrichts et al., 1993), and it has been experimentally documented that the destruction of nerve fibers around the teeth affects the eruption process (Fujiyama et al., 2004) and the activity of osteoclasts (Talic et al., 2003) [36].

Korean scientists [35], who thoroughly investigated clinical cases with a delayed eruption of the lower first molars, found that the average age at the time of diagnosis was 9.2 years, which was much later than the normal period of eruption. This indicates that the delay in the eruption of the first lower molar is poorly diagnosed both by patients and doctors.

In their research, scientists classified the type of retention of the lower first molars into four types in accor- dance with its position relative to the rudiment of the second molar and the second premolar (Fig. 1) [37]. The first type is characterized by the higher position of the first molar with respect to the rudiments of the second molar and the second premolar. In those cases, where the first molar was located above the rudiment of the second molar, but lower than the second premolar, one may speak of type II. In cases of type III, the first molar was located lower than the second molar, but above the second premolar. In type IV, the first molar was located lower than the second molar and the second premolar.

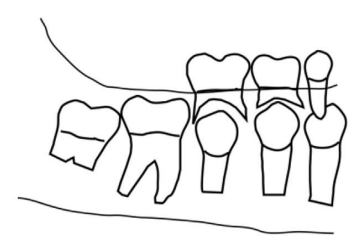

Type I

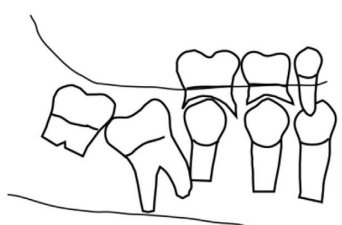

Type III

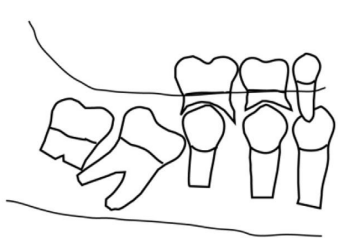

Type II
Figure 1. Classification of retention types

of the first permanent molars of the mandible [37].

Type I was the most common type of retention followed by type III, type IV and type II (Fig. 1). The reason for the delay in eruption in each of the species was the following: Type I had an uncertain etiology. In Type II, many cases of abnormal eruption pathways, cystic changes, and odontogenic tumours were observed. In type III there were unexplained reasons for delay, dental tumours. In type IV cases, there were obvious reasons, such as cystic changes or dental tumours. These results indicate that Type I is unclear in many cases and may be considered as difficult to predict the treatment outcomes.

Korean scientists [38] proposed to determine the depth of retention, the angle of inclination and the space for their eruption on panoramic radiographs. The base line connecting the cement-enamel transition of the adjacent temporary second molar and the upper edge of the alveolar ridge was defined as the reference line of the alveolar bone. In cases where the second temporary molar was removed, the first temporary molar was used as a guide (Fig. 2).

The retention depth was measured as the shortest vertical distance between the baseline of the alveolar bone and the impacted tooth (Fig. 2C). The retention angle of the tooth was measured as the angle between the baseline of the alveolar bone and the longitudinal axis of the tooth (Figures 2A, B). The crown width was measured in the equatorial region of the mandibular first molar (Fig. 2Db). The eruption space was measured as the distance between the vertical lines of the proximal contacts of the second molar and the second premolar relative to the baseline of the alveolar bone (Fig. 2Da). 

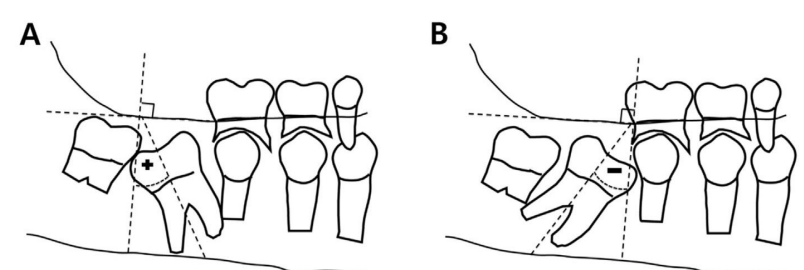

C
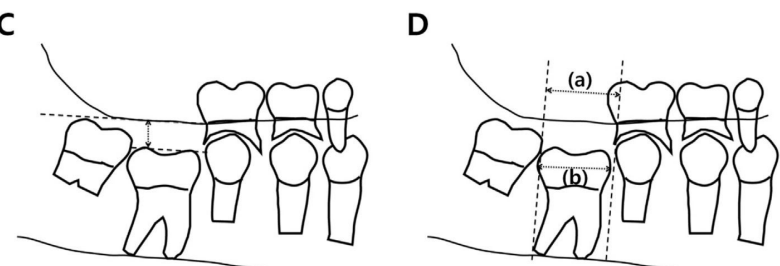

Fig. 2. A, B. Measurement of the retention angle.

$C$. Measurement of the retention depth. D. (a) the eruption space between the permanent second premolar and the second molar; (b) crown width [38].

Scientific studies have shown that surgical exposure of the tooth during retention of the first mandibular molars was effective for further spontaneous eruption. Although, the overall ratio of the teeth, which did not erupt after surgery, was $16.9 \%$, and especially in Type I, it was 6 out of 21 cases. Most of these unsuccessful cases did not have any visible physical barrier that could cause tooth retention and the lack of space. In these cases, an additional equipment-based method of treatment was applied, but this approach also had no result. Taking this into account, the researchers suggested the presence of ankylosis.

Diagnosis of teeth ankylosis is considered difficult for clinicians due to the lack of proper clinical method. Although it is known that ankylosing teeth produce high percussion sound and show low values with periotest, they are not considered to be convincing for measurement due to variable sensitivity [39]. Conventional 2dimensional radiographic examinations, such as periapical or panoramic X-rays, cannot show ankylosing areas on the labial or lingual surfaces of the roots [39, 40]. Multispiral computed tomography in comparison with the cone-beam computer tomography for visualization of the periodontal ligament space more often indicates ankylosing area.

\section{Conclusion}

Literature review revealed a small number of studies on disturbances in the eruption of the first mandibular molar. Most of them were presented with clinical cases. The authors point out the need for further research in this direction. Untimely diagnosis and treatment of the retention of the first permanent molars increases the degree of complications. Therefore, it is important to carry out early diagnosis and treatment by periodic dental examinations starting form 6 years.

\section{References}

1. Ponomareva KG, Dubova MA Dental retention is a topical subject of modern orthodontics. Medicine XXI century 2006; 2(3):67-69.

2. Voronkova AV, Smaglyuk LV Changes in biochemical parameters of oral fluid in patients during the orthodontic treatment with a bracket system under the action of a developed mucosal gel with probiotic. Wiadomości lekarskie. 2018; 71(3), cz I:96-500.

3. Karasiunok AYe, Smahliuk LV The role of parents in motivation for orthodontic treatment for children. Wiadomości lekarskie 2018; 71(3), cz. I:529-533.
4. Tkachenko PI, Guriy O.V., Bilokon S.O. [and others]. Adentia, retention and dystopy of teeth in the practice of surgical dentistry and orthodontics. Stomatologist 2003;12:29-31.

5. Grover PS, Lorton L. The incidence of unerupted permanent teeth and related clinical cases. Oral Surg Oral Med Oral Pathol 1985; 59:420-425.

6. Dachi SF, Howell FV. A survey of 3,874 routine full month radiographs: II. A study of impacted teeth. Oral Surg Oral Med Oral Pathol. 1961;14:1165-1169.

7. Topkara A., Sari Z. Impacted teeth in a turkish orthodontic patient population: prevalence, distribution and relationship with dental arch characteristics. Eur. J. Paediatr. Dent. 2012;13(4):311-316.

8. Kramer RM, Williams AC. The incidence of impacted teeth: a survey at Harlem hospital. Oral Surg Oral Med Oral Pathol. 1970;29:237-241.

9. Raghoebar GM, Boering G, Vissink A, Stegenga B. Eruption disturbance of permanent molars: a review. J Oral Pathol Med. 1991;20:159-166.

10. Ahmad S, Bister D, Cobourne MT. The clinical features and aetiological basis of primary eruption failure. Eur $\mathrm{J}$ Orthod 2006; 28:535-40.

11. Smith CP, Al-Awadhi EA, Garvey MT. An atypical presentation of mechanical failure of eruption of a mandibular permanent molars. Eur Arch Paediatr Dent. 2012;13:152156.

12. Nolla CM. The development of the human dentition. ASDC J Dent Child. 1960;27:254-266.

13. Krogman WM. Biological timing and the dento-facial complex. 3. J Dent Child. 1968;35:328-41.

14. Alimsky AV The mechanism of eruption of permanent teeth and the causes of the formation of anomalies of the dental-maxillary system. Dentistry 2000; 3:25-27.

15. Andreischev AR, Volkov IG The relationship of eruption and formation of the roots of the posterior teeth of the lower jaw. Pediatric dentistry and prevention 2002; 1-2:2830.

16. Khoroshilkina FY, Persin LS, Okushko-Kalashnikova VP. Orthodontics. Book IV. Medicine. 2004; 460.

17. Raghoebar GM, Boering G, Vissink A, Stegenga B Eruption disturbances of permanent molars: a review. Journal of Oral Pathology and Medicine 1991; 20: 159-166.

18. Kelekis-Cholakis Anastasia, Wiltchire William. Root formation in orthodontic traction of an impacted tooth. ORTO IQ. Orthodontics Yearbook. - M.: Index Media. 2006; 1:36-43.

19. Haavikko K: The formation and alveolar and clinical eruption of the permanent teeth. Suom Hammaslaak Tom 1970;66:103-107.

20. Gron AM: Prediction of tooth emergence. J Dent Res. 1962;41:573-585.

21. Andreischev AR, Volkov IG The relationship of eruption and formation of the roots of the posterior teeth of the lower jaw. Pediatric dentistry and prevention 2002;1-2:2830.

22. Marks SC, Schroeder HE Tooth eruption: Theories and facts. Anat. Rec. 1996;245:374-393.

23. Gordon-Zhura GS, Gidon-Zhura GS, Ahmad M, Kharchenko AV Improvement of the method of treatment of impacted canines. Dentistry - yesterday, today and tomorrow, perspective directions of development: international sci. pract. Conf. Feb. 5-6th 2009: theses. - Ivano-Frankivsk 2009; 74.

24. Signe Hauberg Nielsen, Karin Binner Becktorand Inger Kjær. Primary retention of first permanent mandibular molars in 29 subjec. European Journal of Orthodontics 2006; 28:529-534.

25. Kwon JH, Choi BJ, Choi HJ, [et al] .Eruption time and sequence of permanent teeth in students form E-elementary school. J. Korean Acad Pediatr Dent. 2009;36:253-261.

26. Helm S, Seidler B: Timing of permanent tooth emergence in Danish children. Community Dentistry and Oral Epidemiology 1974;2:122-129.

27. Ekstrand KR, Christiansen J, Christiansen MEC: Time and duration of eruption of first and second permanent molars: a longitudinal investigation. Community Dent Oral Epidemiol. 2003;3:344-350. 
28. Lokesh Suri, Eleni Gagari, Heleni Vastardis. Delayed tooth eruption: Pathogenesis, diagnosis, and treatment. A literature review. American Journal of Orthodontics and Dentofacial Orthopedics 2004;49(126):432-445.

29. Sofi a Ahmad, Dirk Bister, Martyn T. Cobourne. The clinical features and aetiological basis of primary eruption failure. European Journal of Orthodontics 2006;28:535-540.

30. Matsuzaki H, Yanagi $\mathrm{Y}$, Ashida M, [et al] . Conditions inhibiting eruption of permanent first molars. Pediatr Dent. 2013;35:67-70.

31. Philipsen HP, Thosaporn W, Grundt G, et al. Odontogenic lesions in opercula of permanent molars in eruption. J Oral Pathol Med 1992;21:38-41.

32. Wu Viet Couong, Avetikov D.S., Shlykova O.A. [et al]. The appearance of odontogenic phlegmon associated with the polymorphic version of $896 \mathrm{~A} / \mathrm{G}$ of the TLR4 gene but not the 2258G/A of the TLR2. Clinical Surgery 2014;10:54-56.

33. Bereket C, Cakir-Ozkan N, Sener I, Kara I, Aktan AM, Arici N. Retrospective analysis of impacted first and second permanent molars in the Turkish population: a multicenter study. Med Oral Patol Oral Cir Bucal 2011;16:874-878.

34. Signe Hauberg Nielsen, Karin Binner Becktor and Inger Kjær. Primary retention of fi rst permanent mandibular molars in 29 subjects. European Journal of Orthodontics 2006;28:529-534.
35. Karin Binner Becktor, Merete Ingemann Bangstrup, Steen Rølling and Inger Kjær. Unilateral primary or secondary retention of permanent teeth, and dental malformations. European Journal of Orthodontics 2002;24:205-214.

36. Kim So Hyun, Young Jin Kim, Hyun Jung Kim , Soon Hyun Nam. Impact and mechanical investigation of implanted mandibular first molar. J Korean Acad Pediatr Dent. 2016;43 (1):51-59.

37. Kim SH, Kim YJ, Kim HJ, Nam SH. Factors affecting spontaneous eruption of impacted mandibular first molars after surgical exposure. Pediatric dental journal 2018;28:25-32.

38. Campbell KM, Casas MJ, Kenny DJ, Chau T. Diagnosis of ankyloses in permanent incisors by expert ratings, Periotest and digital sound wave analysis. Dent Traumatol. 2005;21:206-212.

39. Stenvik A, Beyer-Olsen EM, Abyholm F, Haanaes HR, Gerner NW. Validity of the radiographic assessment of ankylosis. Evaluation of long-term reactions in 10 monkey incisors. Acta Odontol Scand. 1990;48:265-269.

40. Holberg C, Steinhauser S, Geis P, Rudzki-Janson I. Conebeam computed tomography in orthodontics: benefits and limitations. J Orofac Orthop. 2005;66:434-44.

Матеріал надійшов до редакції 12.04.2019 